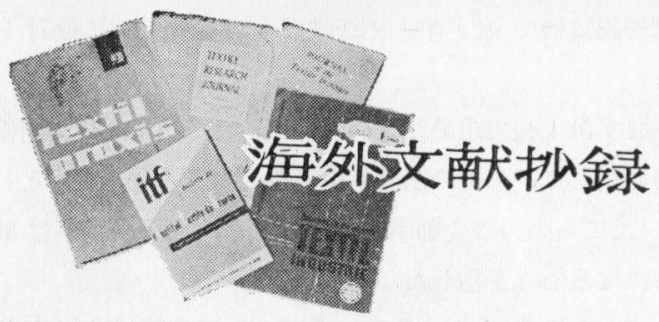

\section{A. 線狳ができるまで}

1966年度の織維性能表；Text. Ind., 119 (1966-8) 〈抄録 6, No. 11，541 (1966) >

防縮性羊毛とモへアを製造するためのコロナ放電法; W. J. Thorsen 他, Text. Res. J., 651 661 (1966 -7)

羊毛綫維に種々の電圧, 周波数, 温度, ガス条件の もとでコロナ放震を行なった。防縮性を与えるための 最適温度は $100 \sim 140^{\circ} \mathrm{C}$ でった。防縮性は 2 秒間の 放射時間でえられた。酸素中では空気中よりよかった が空素中で悪くなった。放電効果の一様性のため緘 維を分散させた，反応割合は電圧，周波数などで増加 した.小さい孔が 400 ～ $800 \mathrm{cps}$ で資料中にとげつき の結果できたが，2つの需極の絶縁体をもつコロナセ ルをつかってとげつきを防ぐととができた。

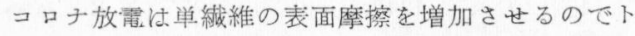
ップのからみむい性や糸の引っ張り強度を増加させ た. 酸や塩基に溶けない性質, 染色, 単蟣維引っ張り 特性の变わらないととなどは, 反応が表皮に限られて いるととを示した。 $\mathrm{pH}$ の低い陽イオン柔軟刘の作用 で防縮性はなくなったが，陽イオン化合物を除去する と防縮性を回復でき,コロナ放電処理は瀻維に正の静 電気を打びさせた。

織物でけガス状の反応物が十分に通らないので防縮 性を与えるととはできなかったが，連続的に処理した カードウェプから防縮性織物はできた。ししか，と のとをスライバーをピンドラフトするとを困難であ った．絨維，織物の手ざわりは一般に処理の程度に依

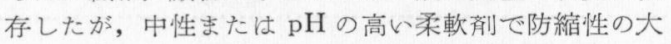
きな減少を伴わないで手ざわりを回復できた。

この方法は電力のみ必要で工程に特別の化学が必要 でなく, 電気代は 0.05 セント/羊毛の $1 \mathrm{lb}$ で被業的 にさいさんに合ら方法である.

空中での放霞加工する前後の羊毛絨維の 表面摩擦

\begin{tabular}{|c|c|c|c|}
\hline \multirow{2}{*}{ 試 } & \multicolumn{3}{|c|}{ 表 面 摩 擦 } \\
\hline & $\begin{array}{l}\text { 对 } \\
\text { スケール }\end{array}$ & $\begin{array}{l}\text { スケール } \\
\text { 方 向 }\end{array}$ & 差 \\
\hline 末処理メディアムトップ & 0.25 & 0.13 & 0.12 \\
\hline 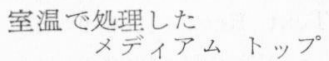 & 0.24 & 0.13 & 0.11 \\
\hline $\begin{array}{l}82^{\circ} \mathrm{C} \text { で処理した } \\
\text { メディアムトップ }\end{array}$ & 0.34 & 0.25 & 0.09 \\
\hline
\end{tabular}

* $82^{\circ} \mathrm{C}$ て $5 \mathrm{~min}, 60 \mathrm{cps}$ で $15 \mathrm{kV}$ 处理

\section{. 布ができるまで}

ウォッシューウエア処理綿織物のひずみ回復性； J.N. Grant 他, Text. Res. J., 642 650 (1966-7)

洗浄してゆるいマーセル加工した織物を dimethyl urea, methylated methylol melamine, formaldehyde で処理した。樹脂量とキニア間の伸びの異なる 織物について試験した。その結果つぎのととがわかっ た.

（1）樹脂を加えるととにより，伸張弹性率は処理中 に伸びるものより少なかった。

（2）破堘伸びは洗浄した織物よりゆるくマーセル加 エした織物の方が大きかった。

（3）試験中のひず回復は, 洗浄した織物はマーセ ル加エした織物より大きかった。ひずみ回復は 平織物の場合，樹脂量を多くすると増加した。

(4) 处理中の伸びは試験中のひずみ回復にほんのわ ずか影瞕をあたえた。

(5)織物のひずみ回復に対する䋞維のひずみ回復の 相関係数はしわ回復に対する織物のひずみ回復 の相関係数より低い.

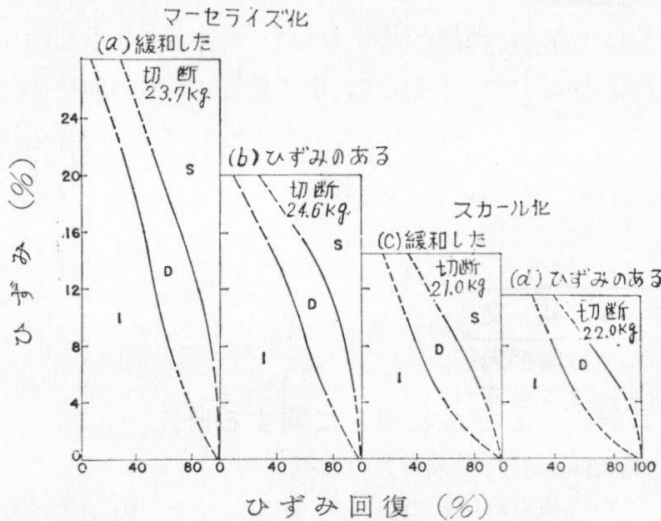

ゆるいマーセライズ加工織物とスカール 加エした織物の引っ張りと回復性につい ての伸張効果

$\langle$ 鈴木>

\section{D. 染 他 仕}

ポリエステル 繊維のサーモソル染色の際の染料の泳 動; W. Fester 他, Textil-Praxis, 520〜522（1966 $-7)$

ポリエステル㵶維の染色には今日サーモソ゚ルプロ セスが多く用いられ，研究文献も多い。しかしサーモ ゾル法ではしばしば不均一染色が問題になり, 特に布 の耳部の不均一染や布の端末の不均一染が把こる. か かる不均一染の原因を解明するために重要なサーモゾ ルプロセス中に扣りる布の横断面での染料の泳動を 追求する実験を行なったと述へ, 染色実施条件, 予備乾 燥せず直接固定の時の染料泳動，不均一乾燥による染 料分布, 混合染料使用の際の布横断面中の染料分布, 実 験検討の各項について誌し, 染料の泳動が主として乾 燥プロセス中に把とり，との泳動は乾燥条件にいちじ るしく依存するととが布の横断面観察によって示すと そができる．正しい固定プロセス中では布横断面中で 
の染料の泳動々なく, 単繊維中に把いてのみ染料が泳 動する。乾燥中の染料の泳動は乾燥機内の乾燥条件の 均一性に主々して依存するが，な拓乾燥速度に依存す ると述へる。

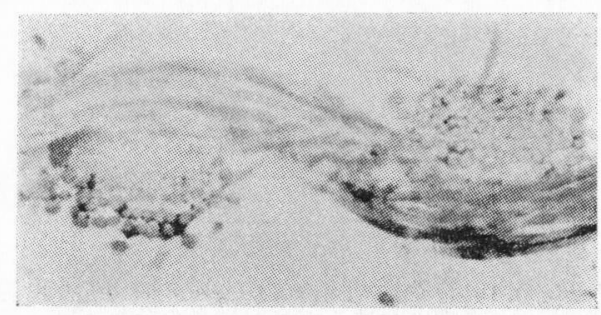

片側吹きこみで予備乾燥された布の染料分布

$<$ 篠田 >

\section{I. 最終裂品の慗遗と更正}

永久プレス用の Avril 繊維; I. H. Welch, Text. Ind., $74 \sim 80,140(1966-8)<$ 抄録 6, No. 11, 576 (1966)〉

E. 試 踰

糸の摩擦係数と温湿度との関係; N. Fieles-Kahl 他, Textil-Praxis, 332 336 (1966-5)<抄録 6, No. 11, $580(1966)>$

系の糜擦係数と温湿度との関係（続報）; N. FelesKahl 他, Textil-Praxis, 402 405 (1966-6) <抄録 6. No. 11, 580 (1966)>

\section{G. 基磷科学}

衣料生理学的因子としての緎維材料と布構造（第 1 報）選定試験条件における緎維材料の熱的生理学作 用; F. W. Behmann, Melliand Textilber., 931 $933(1966-8)$

繊維材料の肉体作用に対するいままでの研究交献を 示し，とれらが種々の事実を示したが，とこでは種々の

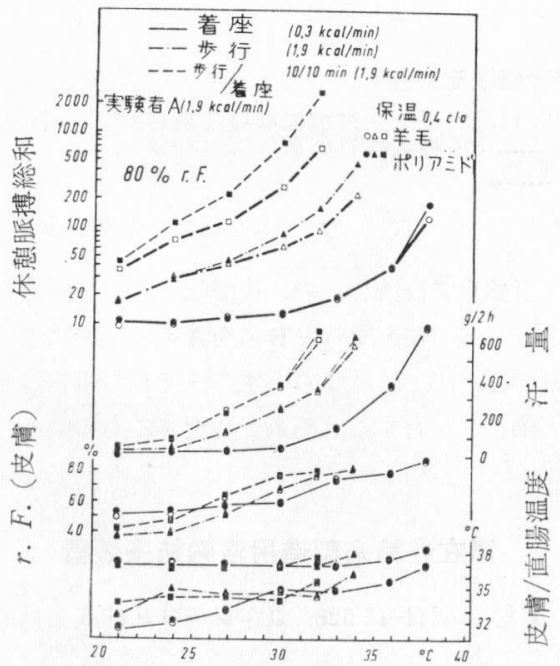

$80 \%$ の一定空気温度と種々作業条件によ る時の室温による䋞維材料生理学的作用 5 回の実験よりの平均值
感受量のみならず気候の条件や労働条件ゃ肉体のトレー ニンク゚を变えて実験し, あわせて緎維材料としての羊毛 とポりアミドの比較文行なったと述へ, 使用布の性質, 実験の 3 人の体格, 実験方法, 結果, 環境条件による負 荷の影響, 肉体順応の影響, 結果の検討について誌して 托り，羊毛托よび合成緎維のある種の布についての影響 の生理学的テストを行なった。その時, 基本ファクタ 一の気候条件, 労働条件, 身体トレーニングの度合いを 变えた。肉体休息や活動が低度では繊維材料の影響はな い. 各人の持続肉体能力限度に近ついた時の疲労度はポ リアミド瀻維の場合の方が大きい. そしてリズミカルな 活動で疲労度はさらに增したが肉体トレーニングによ って減少する。しかしとれらの影響は休㓤時間中の脈博 総和にのみ現われ, 皮膚温度, 直胉温度, 皮虔水分ゃ発 汗度は一般標準量と差は見られないと述へる。〈篠田〉

織維学会 25周年記念国際学会 "㵶維の超分子構造"; Text. Res. J., (1966-7)

。高分子に応用される電子顕徽鏡の

Histochemical 技術の応用

P. Kassenbeck

。繊維の X線回析写真を判断する光回析技術

C. A. Taylor

。線型合成高分子の分子, 超分子 パラクリスタリン構造Ｒ. Hosemann

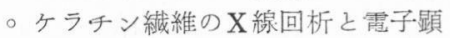
微鏡の問題点 H. J. Woods 高分子の球晶化 H. D. Keith

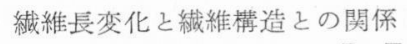

D. E. Bosley

。結晶化工程について $\quad$ P. H. Geil

。緎維中の分子配向 W. O. Statton

天然繊維, 再生繊維の微細構造

一軸遈伸之異方性 F. H. Muller

高分子鎖の屈曲々緎維形成の分子理論

P. H. Lindenmeyer

。染料の拡散に対する緎維構造の関係

B. Skeldon Sprague

。結晶性高分子の变形 M. Horio,

K. Kobayashi,

Y. Nishijima

。結晶性高分子の变形速度についての物理研究

R. S. Stein

。機械的性質から䆃かれたケラチンの
構造について
B. M. Chapman,
M. Feughelman

○ケラチンの高サルファプロティン

綫維構造之性質々の関係 J. M. Gillespie

○ 2 相構造纎維の性質についての解釉

J. W. S. Hearle

〈鈴木 $>$

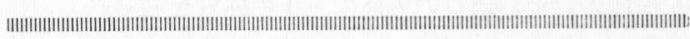

この欄には, 多くの会員加らの要望に応えて海外交献 を紹介する。海外資料編集委員会編集による「海外緎維 文献抄録」(1966-11) のうちより, 比較的重要々思わ れる研究論文に類するものを選択して掲載した。すた題 目のみ所載の\&の汇「海外瀻維技術文献集」に揭載予定 のものである.

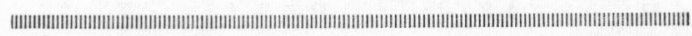

